\title{
Phenetic Analysis of Morphological and Molecular Traits in Acanthaceae Juss
}

\author{
Usama K. Abdel-Hameed*, Mohamed E. Tantawy, Mohamed A. Salim, Magdy M. Mourad, \\ Ishak F. Ishak \\ Botany Department, Faculty of Science, Ain Shams University, Cairo, Egypt \\ Email: ${ }^{*}$ usama abdelhameed@sci.asu.edu.eg
}

Received November 2014

\section{Abstract}

Acanthaceae has received considerable taxonomic attention at the familial, subfamilial, tribal and subtribal levels. Several different infra-familial classifications have been proposed for the Acanthaceae, but no taxonomic consensus has yet been reached. The main objective of the present study is to throw light on the phenetic relationships and to explore the contribution of morphological and molecular characters in systematics of Acanthaceae. The morphological data viz. macromorphology, stomatography, lamina architecture and ISSR profiles of 30 Egyptian acanthaceous taxa were investigated. The phenetic analysis using NTSYS-PC version 2.02 software based on 55 potentially informative morphological and molecular characters indicated that the used morphological and ISSR criteria is likely to be useful and valuable taxonomic traits. The morphological characters and ISSR aspects of all the studied species produced a phenogram that showed two series; one of them had two subseries, the first one comprised only three taxa while the second divided into two clusters, each contained two groups. The delimitation and the membership of the studied taxa clearly merit additional study using more criteria. The phenetic analysis of both morphological and molecular attributes clarified the segregation of genus Avicennia as a distinct identity away from Acanthaceae. Acanthus mollis \& A. montanus are isolated in its own series that comparable to tribe Acantheae of the current taxonomic systems. The studied species of Thunbergia are gathered its own subseries that comparable to tribe Thunbergiae and Ruellia in its own group that comparable to tribe Ruellieae.

\section{Keywords}

Phenetic Analysis, Numerical Taxonomy, Morphology, ISSR, Acanthaceae

\section{Introduction}

Acanthaceae has received considerable taxonomic attention at the familial, subfamilial, tribal and subtribal levels by various workers, the earlier system of infra-familial classifications of Acanthaceae is that of [1], he subdivided the family on the basis of two to four stamens and recognized either genera viz. Acanthus, Barleria,

\footnotetext{
${ }^{*}$ Corresponding author.
}

How to cite this paper: Abdel-Hameed, U.K., Tantawy, M.E., Salim, M.A., Mourad, M.M. and Ishak, I.F. (2015) Phenetic Analysis of Morphological and Molecular Traits in Acanthaceae Juss. Journal of Biosciences and Medicines, 3, 18-34. 
Blepharis, Dianthera, Dilvaria, Justicia, Ruellia and Thunbergia. Since then, the family has been subjected to various taxonomic treatments and has received attention from many authors; [2] recognized four subfamilies viz. Nelsonioideae, Mendoncioideae, Thunbergioideae and Acanthoideae on the basis of types of fruits, number of ovules and presence or absence of retinacula and their shape. He further subdivides Acanthoideae into two sections (Contortae and Imbricatae).

Several different infra-familial classifications have been proposed for the Acanthaceae, but no taxonomic consensus has yet been reached [3]. On the basis of morphology it has been suggested that the family is not "natural" [4] [5]. Molecular data has helped botanists move towards a more clearly circumscribed family, by supporting the inclusion of Avicennia [6], Thunbergia and others that often receiving their own family status [7]. This has, however, led to a situation where the family cannot be definitively and distinctively constrained by morphological characters [8]. Recent work on the evolution and the diversification of the Acanthaceae provides a phylogenetic context for assessing the taxonomic significance of possible characters (including micro-morphological structures) within the family [9].

Two subfamilies were recognized by [10]; Anechmatacantheae (without retincula) and Echmatacantheae (with retinacula). The former comprises two tribes viz. Thunbergieae and Nelsonieae, which together include [2]'s Thunbergioideae, Nelsonioideae and Mendoncioideae. The latter has nine tribes (Hygrophileae, Ruellieae, Barlerieae, Acantheae, Aphelandreae, Gendarusseae, Eranthemeae, Dicliptereae and Andrographideae) comprising [2]'s Acanthoideae.

The family was split by [11] and [12] into three suborders viz.; Thunbergideae (with Thunbergia), Ruellideae (with all the genera having contorted corolla lobes in bud) and Acanthideae (genera with imbricate corolla lobes). Tribes and sub-tribes were recognized within last two suborders in this system; Nelsonieae is treated as a tribe of Ruellideae, tribes Gendarussae and Dicliptcreae are amalgamated to form the tribe Justicieae with a number of sub-tribes. The present family was classified by [13] into five tribes; Thunbergieae, Nelsonieae, Ruellieae, Acantheae and Justicieae. The tribe Thunbergieae and Nesonieae correspond to [2]'s Thunbergioideae and Nelsonioideae respectively while Acantheae, Ruellieae and Justicieae together constitute his Acanthoideae. The number of tribes was reduced by [14] to a total of five with Thunbergieae being reduced to tribal level; the Ruellieae, Nelsonieae and Acantheae remaining mostly unchanged. However in this system the tribe Justicieae was expanded, comprising the previously recognized tribes of Barlerieae, Andrographideae and Asystaceae at the sub-tribal level. Apart from the reduction in the rank of some tribes to sub-tribes, this classification is similar to [11] [12]'s treatment.

For the first time Thunbergiaceae was raised as a separate family by [15] accommodating the first three subfamilies of Acanthaceae sensu [2], [13]'s Acanthaceae comprising [2]'s subfamily Acanthoideae only. Two subfamilies were formulated by [16]; Thunbergioideae and Acanthoideae that correspond to [13]'s Thunbergiaceae and Acanthaceae and [10]'s Anechmatacantheae and Echmatacantheae. [14]'s Thunbergioideae also includes the first three sub-tribes of [2]. [17] comprised five tribes and sixteen sub-tribes, this classification has been accepted by many taxonomists and is in use even today [18]-[24]. In other works [25]-[28], it is well appreciated, though with some modifications.

The extensive work of [5] was thrown much light on the classification of the family. According to him [2]'s Thunbergioideae and Mendoncioideae show greater affinity to Bignoniaceae and Pedaliaceae than to latter's Acanthoideae; and his Nelsonioideae is very much related to the tribe Rhinantheae of Scrophulariaceae. In this consideration Bremecamp suggested to place Nelsonioideae near Rhinantheae as long as the latter is placed in Scrophulariaceae. But this reshuffling has received varying response. He was also recognized two subfamilies viz. Acanthoideae and Ruellioideae, the former with five tribes and the latter with seven tribes. Along with pollen characters [5] did use other supporting characters such as nature of corolla, fruits and seeds. But within Justiceae there are a number of genera with uncertain positions [5]. He proposed many changes in the generic limits.

From the architectural point of view (Considering the Acanthaceae) the major venation pattern of leaves were pinnate camptodromous with eucamptodromous or festooned brochidodromous secondaries, pinnate craspedodromous in Acanthus ilicifolius and acrodromous in Lepidagathis trinervis. Intersecondary veins are common [29]. The foliar epidermal characteristics were investigated by [30] and [31] in some Acanthaceae and reported that the leaves mostly hypostomatic with few exceptions, Stomata are generally diacytic, other types viz. anomocytic, amphidiacytic, staurocytic, anomotetracytic, polocytic, axillocytic, pericytic, co-pericytic, and amphipericytic, were of rare to occasional occurrence. Stomatal anomaly as single guard cell, aborted guard cells, contiguous stomata and stomata with arrested development have been noted. 
There have been some molecular systematic studies specifically addressing the higher level systematics of Acanthaceae [3] [32]-[34]. The genes used for these studies were rbcL, ndhF, trnL-trnF and trnL-trnF combined with ITS, respectively. The rbcL data of [32] was re-analyzed by [3] but provided limited resolution within Acanthaceae. The strict consensus tree of [3] and [34] resolved Acanthaceae sensu [2] as a group. These analyses demonstrated that there is no support for separating Thunbergia from Acanthaceae as proposed by [5]. The strict consensus tree of [33] resolved Acanthaceae sensu [2] with the exception of Elytraria (Nelsonioideae) which remained unresolved. [35] showed that Thunbergia, are a natural group based upon the shared possession of woody bristles on the anthers, lack of an endothecial cell layer, elongated connective tips and poricidal opening of the thecae.

The main objective of the present study is to throw light on the phenetic relationships and to explore the contribution of morphological and molecular characters in systematics of Acanthaceae.

\section{Materials and Methods}

\subsection{Sampling}

The present study was conducted on 30 species of Acanthaceae in Egypt belonging to 17 genera that were collected from some Egyptian botanical gardens. Blepharis edulis and Avicennia marina were collected from natural habitats in Sinai Peninsula (Table 1). The identification of wild taxa was taken by the aid of [36] and [37], while the horticultural taxa with the help of [38] and [39]. The taxa were further matched against the dried specimens in the Herbaria at Ain Shams University, Faculty of Science (CAIA), Cairo University, Faculty of Science (CAI), Flora and Phytotaxonomy Research Department (CAIM) and Orman Botanical Garden (Geiza). Voucher specimens of the studied species were kept in CAIA.

\subsection{Morpholoical Investigation}

Macromorphological characters were examined directly from the investigated specimens. Stomatography (LM and SEM) was carried on the bases of traditional method of [40]. A Reichert Microstar IV microscope was used for microphotographs documentation at the Plant Taxonomy Research Laboratory, Botany Department, Faculty of Science, Ain Shams University, Cairo, Egypt. Lamina vein architecture was done according to [41]. Descriptive terminology of epidermal characteristics based on [41]-[44] while leaf architectural terminology follows [41].

\subsection{Molecular Investigation}

Genomic DNA extraction was performed as suggested by Qigene multisource Genomic DNA Mini-Prep Kit (USA, cat. No. Ap-MN-MS-GDNA-50). DNA samples of each plant were analyzed individually to detect intraspecific variations and bulked to detect inter-specific variations. An initial screening of 20 ISSR primers (successfully utilized in other plant species, was performed in order to test their readability and amplification profiles for polymorphism). After this screening procedure, five ISSR primers were selected (Table 2). Polymerase chain reactions (PCR) were carried out according to [45]. The products of ISSR based PCR were detected by electrophoresis on agarose gel (1.2\% in $1 \times$ TBE buffer), then stained with ethidium bromide $(0.3 \mathrm{ug} / \mathrm{ml})$. Amplicon sizes were estimated using $1 \mathrm{~Kb}$ DNA standard (Bioron, Germany). Reproducible bands visualized on the gels were scored using a binary code (1/0) for their presence or absence based on the UVP gel documentation system (Gel Works ID advanced software, UVP).

\subsection{Phenetic Analysis}

Unweighted Pair-Group Method using Arithmetic Averages with SAHN function [46] was used to estimate states of characters variation among the species, each taxa was considered as operational taxonomic unit (OTU) and states of characters analysed as binary characteristics. The formation of groups was depending on the values of similarity. All computations were carried out by the aid of the NTSYS-PC version 2.02 [47].

\section{Results}

The morphological characters viz. macromorphology of the whole plants, stomatography, lamina architecture of 
Table 1. The studied taxa of acanthaceae and avicennia marina.

\begin{tabular}{|c|c|}
\hline 1 & Acanthus mollis L.-Sp. Pl. 2: 639. 1753 [1 May 1753] (IK) \\
\hline 2 & A. montanus T. Anderson-J. Proc. Linn. Soc., Bot. 7: 37. 1863 [1864 publ. 1863] (IK) \\
\hline 3 & Anisacanthus virgularis Nees-Prodr. [A. P. de Candolle] 11: 445. 1847 [25 Nov 1847] (IK) \\
\hline 4 & Aphelandra squarrosa Nees-Fl. Bras. (Martius) 9: 89. (IK) \\
\hline 5 & Barleria cristata L.-Species Plantarum 21753 (APNI) \\
\hline 6 & B. prionitis L.-Sp. Pl. 2: 636. 1753 [1 May 1753] (IK) \\
\hline 7 & Blepharis edulis (Forssk.) Pers. \\
\hline 8 & $\begin{array}{c}\text { Eranthemum nervosum R. Br. ex Roem. \& Schult.-Syst. Veg., ed. } 15 \text { bis } \\
\text { [Roemer \& Schultes] 1: 174. } 1817 \text { [Jan-Jun 1817] (IK) }\end{array}$ \\
\hline 9 & Fittonia argyroneura E. Coem.-Fl. des Serres xvi. (1865-67) 103. (IK) \\
\hline 10 & $\begin{array}{l}\text { F. verschaffeltii (Lem.) Van Houtte-Fl. des Serres 15: 186. 1865; } \\
\text { cf. R.K.Brummitt in Curtis’s Bot. Mag., 182(4): 167. } 1979 \text { (IK) }\end{array}$ \\
\hline 11 & Hypoestes sanguinolenta Hook-Bot. Mag. 91: t. 5511. 1865 (IK) \\
\hline 12 & Jacobinia carnea (Lindl.) G. Nicholson-Ill. Dict. Gard. ii. 206 (1885) (IK) \\
\hline 13 & Justicia adhatoda L.-Sp. Pl. 1: 15. 1753 [1 May 1753] (IK) \\
\hline 14 & J. betonica L.-Sp. Pl. 1: 15. 1753 [1 May 1753] (IK) \\
\hline 15 & J. brandegeeana Wassh. \& L. B. Sm.-Fl. Ilustr. Catarin. Pt. 1, Acantac., 102 (1969) (IK) \\
\hline 16 & J. gendarussa Burm. f.-Fl. Ind. (N. L. Burman) 10. 1768 [1 Mar-6 Apr 1768] (IK) \\
\hline 17 & J. spicigera Schltdl.-Linnaea 7: 395. 1832 (IK) \\
\hline 18 & Odontonema cuspidatum (Nees) Kuntze-Revis. Gen. Pl. 2: 494. 1891 [5 Nov 1891] (GCI) \\
\hline 19 & Pachystachys lutea Nees-Prodr. [A. P. de Candolle] 11: 320. 1847 [25 Nov 1847] (IK) \\
\hline 20 & $\begin{array}{l}\text { Pseuderanthemum atropurpureum Radlk.-Sitzungsber. Math.-Phys. } \\
\text { Cl. Königl. Bayer. Akad. Wiss. München 13: 286. } 1884 \text {; nom. inval. (IK) }\end{array}$ \\
\hline 21 & P. bicolor Radlk.-Sitzungsber. Math.-Phys. Cl. Königl. Bayer. Akad. Wiss. München 13: 286. 1884; nom. inval. (IK) \\
\hline 22 & Ruellia alba Nees-Fl. Bras. (Martius) 9: 55 (IK) \\
\hline 23 & $\begin{array}{l}\text { R. brittoniana Leonard-J. Wash. Acad. Sci. xxxi. } 96 \text { (1941); } \\
\text { Fernald in Rhodora, xlvii. } 7 \text { (1945),cum descr. ampl. et emend (IK) }\end{array}$ \\
\hline 24 & R. glabra B.Heyne ex Roth-Nov. Pl. Sp. 312. 1821 [Apr 1821] (IK) \\
\hline 25 & R. humilis Nutt.-Trans. Amer. Philos. Soc. ser. 2, 5: 182. 1835 [late 1835] (IK) \\
\hline 26 & Sanchezia nobilis Hook. f.-Bot. Mag. 92: t. 5594. 1866 (IK) \\
\hline 27 & Thunbergia alata Bojer ex Sims-Bot. Mag. 52: t. 2591. 1825 (IK) \\
\hline 28 & T. erecta T. Anderson-J. Proc. Linn. Soc., Bot. 7: 18. 1863 [1864 publ. 1863] (IK) \\
\hline 29 & T. grandiflora Roxb.-Edwards’ Botanical Register 61820 (APNI) \\
\hline 30 & Avicennia marina (Forssk.) Vierh.-Denkschr. Kaiserl. Akad. Wiss., Wien. Math.-Naturwiss. Kl. lxxi. 435 (1907) (IK) \\
\hline
\end{tabular}

Table 2. ISSR primer names, sequence, and annealing temperature (Ta).

\begin{tabular}{cccc}
\hline No. & Primer Name & Sequence & Ta $\left({ }^{\circ} \mathrm{C}\right)$ \\
\hline 1 & 890 & ACG $(\mathrm{GT})_{7}$ & $50^{\circ} \mathrm{C}$ \\
2 & $17898 \mathrm{~b}$ & $(\mathrm{CA})_{6} \mathrm{GT}$ & $40^{\circ} \mathrm{C}$ \\
3 & 835 & $(\mathrm{AG})_{8} \mathrm{CC}$ & $55^{\circ} \mathrm{C}$ \\
4 & 851 & $(\mathrm{GT})_{8} \mathrm{CG}$ & $55^{\circ} \mathrm{C}$ \\
5 & 809 & $(\mathrm{AG})_{8} \mathrm{G}$ & $53^{\circ} \mathrm{C}$ \\
\hline
\end{tabular}


all the studied species were summarized in Tables A1-A4. The profiles of ISSR that illustrated in Figure 1 clarified that primer 890 produced 15 total bands (three unique and three monomorphic), the remainder nine polymorphic bands reaching the polymorphism $80 \%$, primer $1789 \mathrm{~b}$ generated 14 bands (one unique and four monomorphic) with $71.4 \%$ polymorphism ratio where the polymorphic bands were nine, 12 polymorphic bands produced by primer 835 in addithion to one monomorphic and two unique bands the polymorphism reached 93.3\%, no unique bands were generated by both primers 851 and 809 the former produced six monomorphic bands and six polymorphic ones giving $60 \%$ polymorphism while the latter produced three monomorphic bands and 14 polymorphic ones increasing the polymorphism to $82.3 \%$. Coding of character states was produced in Table 3. The obtained cladogram (Figure 2) showed two series, the second one had two subseries, one of them divided into two clusters, each one divided into two groups.

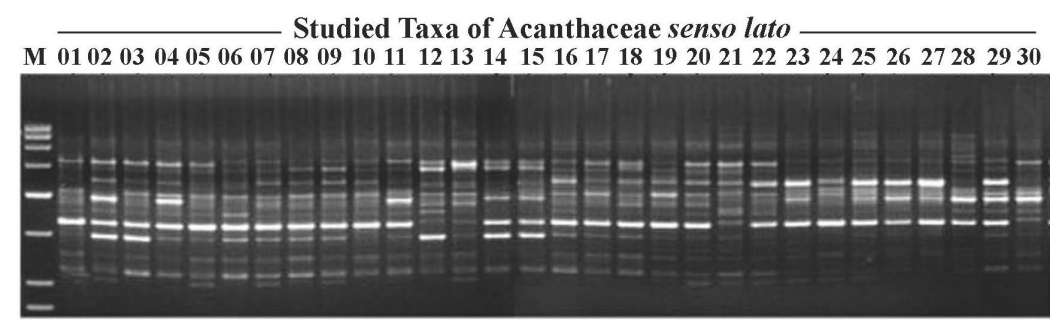

(a)

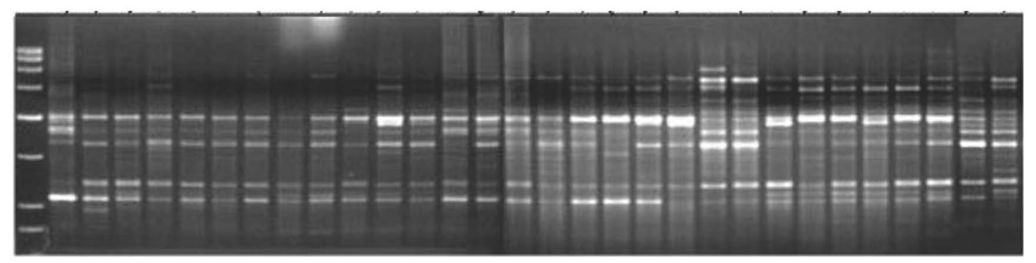

(b)

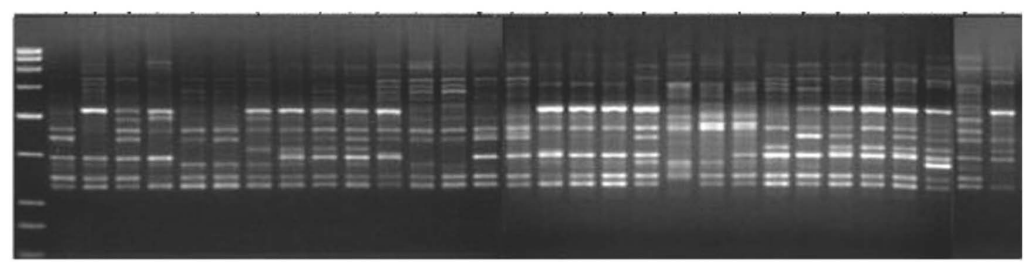

(c)

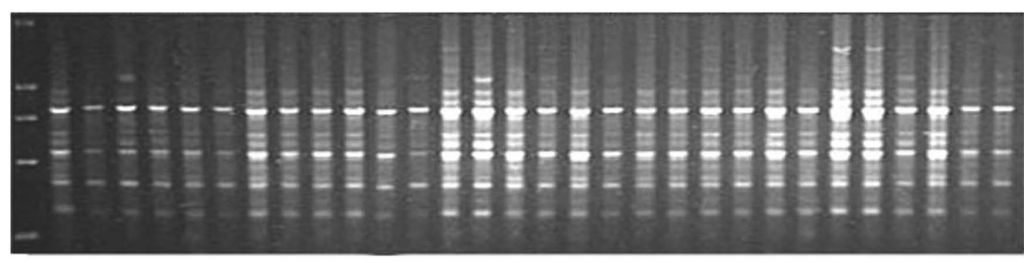

(d)

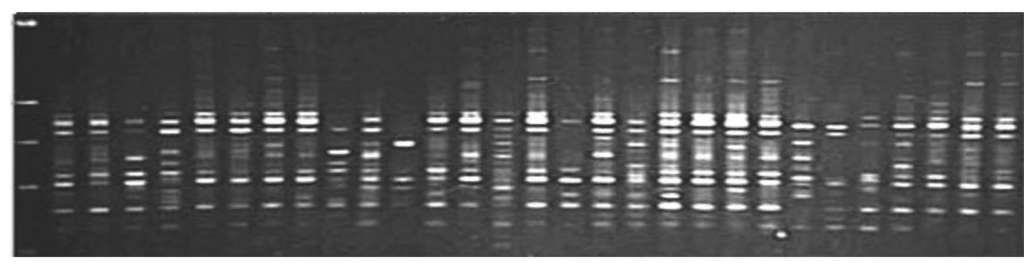

(e)

Figure 1. ISSR profiles of the studied taxa of Acanthaceae senso lato generated by (a) primer 890; (b) primer 1789b; (c) primer 835; (d) primer 851; (e) primer 809. 
Table 3. Morphological \& molecular characters (55), their states (172) and codes of taxa under investigation.

\begin{tabular}{|c|c|c|}
\hline No. & Character & Character State and its (Code) \\
\hline 1 & Duration & Perennial (1), Annual (0) \\
\hline 2 & Gross morphology & Shrub: present (1) Absent (0), Subshrub: present (1) Absent (0), Herb: present (1) Absent (0) \\
\hline 3 & habit & Climbing (1), Erect (0) \\
\hline 4 & Leaf composition & Lobed (1), Simple (0) \\
\hline 5 & Leaf arrangement & Decussate (1), Superposed (0) \\
\hline 6 & Leaf shape & $\begin{array}{l}\text { Lanceolate: present (1) Absent (0), Ovate: present (1) Absent (0), Obovate: } \\
\text { present (1) Absent (0), Oblonovate: present (1) Absent (0), Cordate: present (1) Absent (0) }\end{array}$ \\
\hline 7 & Leaf margin & $\begin{array}{l}\text { Entire: present (1) Absent (0), Spiny: present (1) Absent (0), } \\
\text { Sinuate: present (1) Absent (0), Crenate: present (1) Absent (0) }\end{array}$ \\
\hline 8 & Leaf apex & Acute: present (1) Absent (0), Acuminate: present (1) Absent (0), Obtuse: present (1) Absent (0) \\
\hline 9 & Leaf texture & Glabrous: present (1) Absent (0), Hairy: present (1) Absent (0), Spiny: present (1) Absent (0) \\
\hline 10 & Leaf base & $\begin{array}{l}\text { Cuneate: present (1) Absent (0), Rounded: present (1) Absent (0), } \\
\text { Cordate: present (1) Absent (0), Truncate: present (1) Absent (0) }\end{array}$ \\
\hline 11 & Bract & Present (1) Absent (0) \\
\hline 12 & Sepals number & Five: present (1) Absent (0), Four: present (1) Absent (0), Numerous: present (1) Absent (0) \\
\hline 13 & Sepals union & United (1) Free (0) \\
\hline 14 & Corolla shape & 1-lipped: present (1) Absent (0), Bilabiate: present (1) Absent (0), Funnel: present (1) Absent (0) \\
\hline 15 & Petals texture & Hairy (1) Glabrous (0) \\
\hline 16 & Corolla tube length & Long (1) Short (0) \\
\hline 17 & Stamens number & two (1) Four (0) \\
\hline 18 & Stamens fertility & Sterile (1) Fertile (0) \\
\hline 19 & Stamens length & Exerted (1) Included (0) \\
\hline 20 & Stamens symmetry & Unequal (0) Equal (1) \\
\hline 21 & Stamens texture & Hairy (1) Glabrous (0) \\
\hline 22 & Ovary texture & Hairy (1) Glabrous (0) \\
\hline 23 & Stigma shape & Forked: present (1) Absent (0), Single: present (1) Absent (0), lobed: present (1) Absent (0) \\
\hline 24 & Basal nectary disc & present (1) Absent (0) \\
\hline 25 & $1^{\mathrm{ry}}$ vein category & Basal actinodromus (1) Pinnate (0) \\
\hline 26 & $2^{\text {ry }}$ vein category & $\begin{array}{l}\text { Festooned semicraspedoromum: present (1) Absent (0), Semicraspidodromus: present (1) } \\
\text { Absent (0), Festooned brochidodromus: present (1) Absent (0), Brochidodromus: present (1) } \\
\text { Absent (0), Eucamptodromous: present (1) Absent (0), Weak brochidodromus: present (1) Absent (0) }\end{array}$ \\
\hline 27 & $2^{\mathrm{ry}}$ vein spacing & $\begin{array}{l}\text { Uniform: present (1) Absent (0), Irregular: present (1) Absent (0), } \\
\text { Decreasing toward base: present (1) Absent (0), Increase toward base: present (1) Absent (0) }\end{array}$ \\
\hline 28 & $2^{\mathrm{ry}}$ vein angle & $\begin{array}{l}\text { Abruptdly increase to base: present (1) Absent (0), Uniform: present (1) Absent (0), Smoothly } \\
\text { increase toward base: present (1) Absent (0), Smoothly decrease toward base: present (1) Absent (0) }\end{array}$ \\
\hline 29 & Intersecondary veins & Absent: present (1) Absent (0), Weak: present (1) Absent (0), strong: present (1) Absent (0) \\
\hline 30 & $3^{\text {ry }}$ vein category & $\begin{array}{l}\text { Alternate percurrent: present (1) Absent (0), Random reticulate: present (1) Absent (0), } \\
\text { Opposite percureent: present (1) Absent (0), Mixed opp/alte: present (1) Absent (0), } \\
\text { Regular polygonal reticulate: present (1) Absent (0) }\end{array}$ \\
\hline 31 & $3^{\text {ry }}$ vein course & $\begin{array}{l}\text { Straight: present (1) Absent (0), Exmedially ramified: present (1) Absent (0), } \\
\text { Admedially ramified: present (1) Absent (0), Sinuous: present (1) Absent (0) }\end{array}$ \\
\hline
\end{tabular}




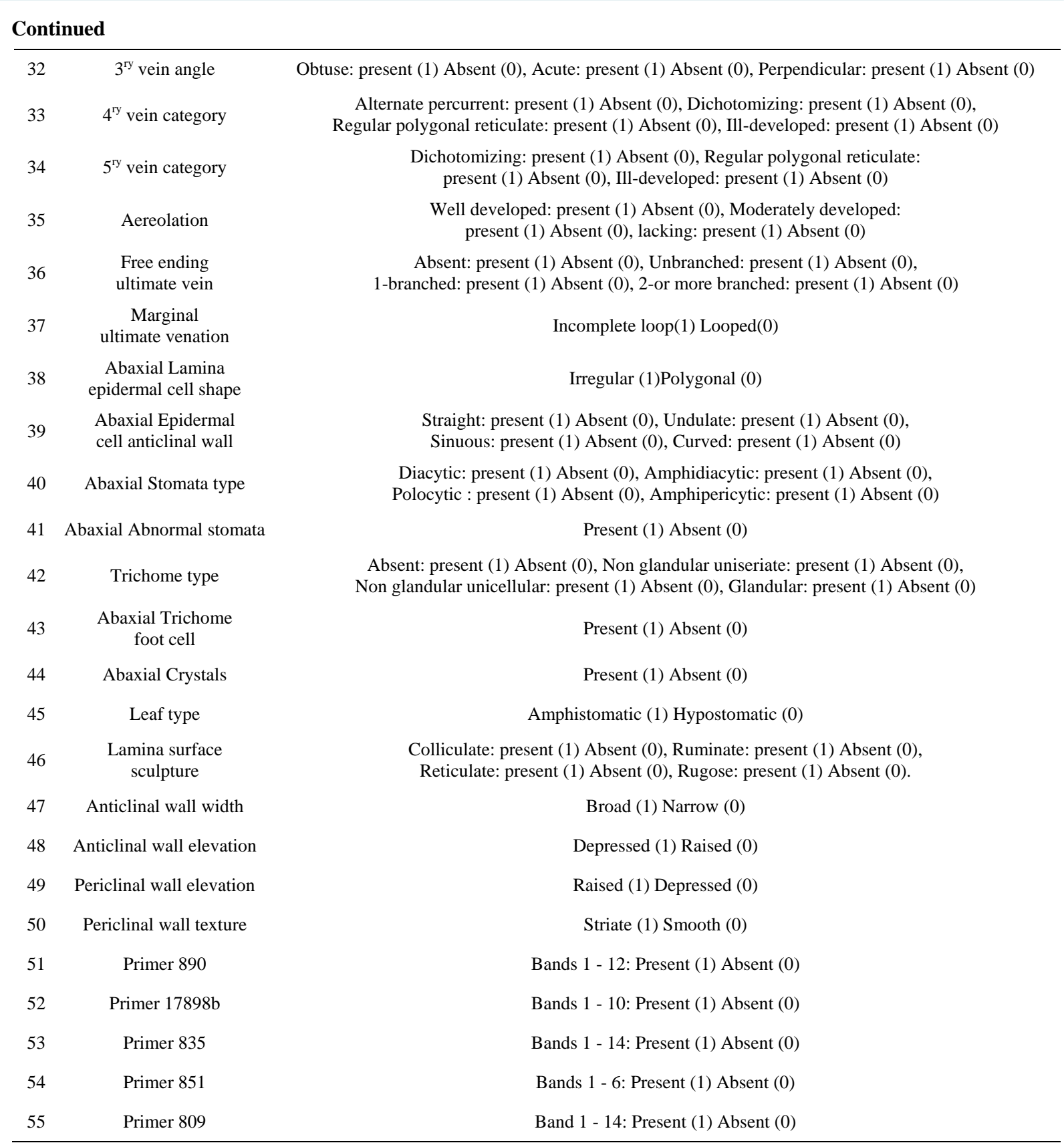

\section{Discussion}

The phenetic analysis of both morphological and molecular attributes generated a dendrogram that clarifies the segregation of genus Avicennia as a distinct identity owing to three characters viz. the shrub habit, the presence of moderately developed areolation and the ocellate adaxial surface sculpture. This is in accord with [6] who used data from both the chloroplast and the nuclear genome, that implied the black mangrove genus Avicennia, usually treated as a separate family in Lamiales or as a genus within Verbenaceae, but more recently has been placed by some botanists in the monogeneric family Avicenniaceae and recent phylogenetic study [48] has suggested that Avicennia is derived from Acanthaceae but is included in that family according to [49].

The remaining taxa under investigation distributed into two main series; Series I included two studied species; Acanthus mollis \& A. montanus at a taxonomic distance 1.232. This series is characterized by lobed leaf composition and exmedially ramified 3rd vein category. [2] [4] [5] [10] [13] [14] [50] put Acanthus in tribe Acantheae. 


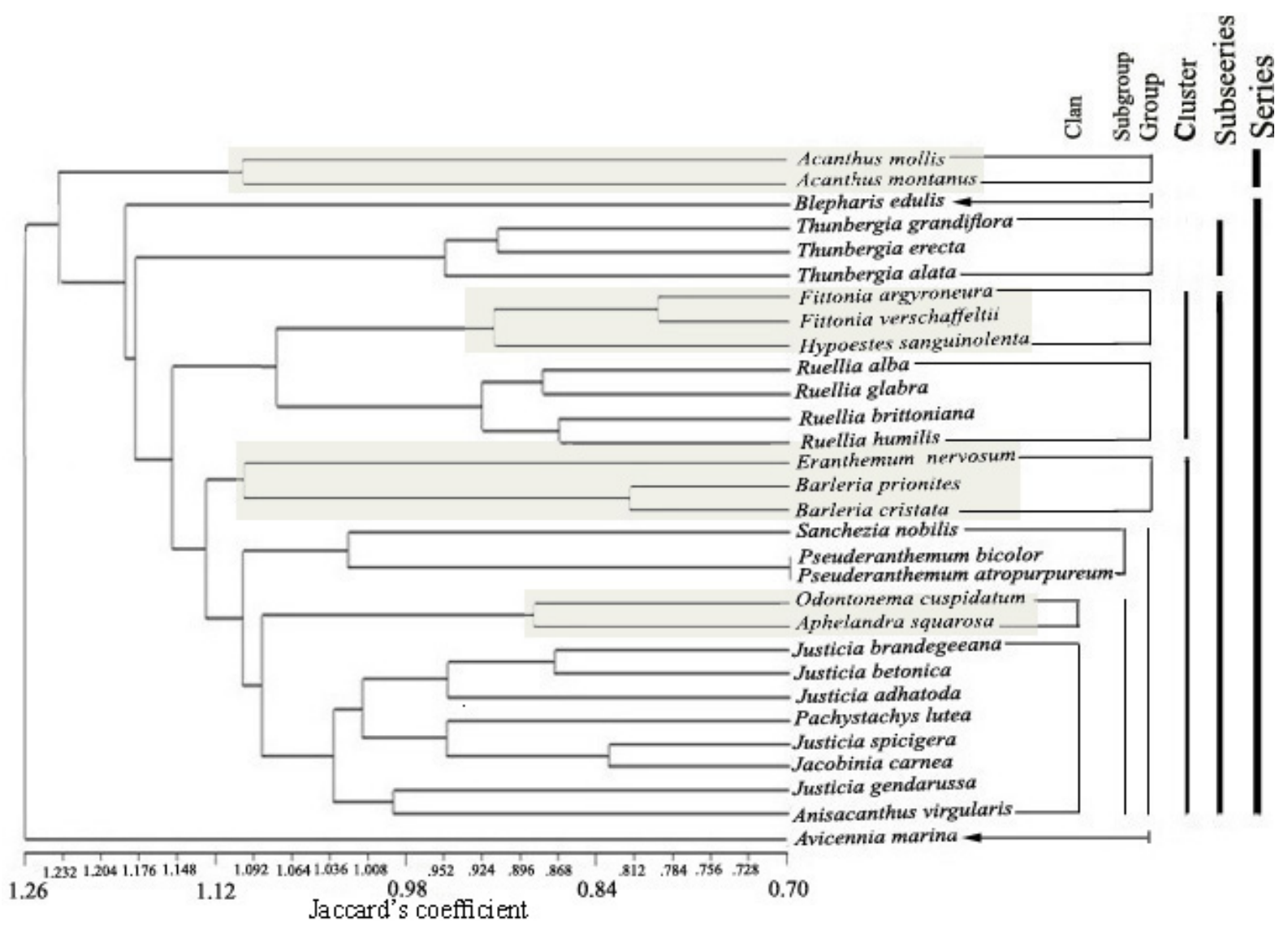

Figure 2. UPGMA dendrogram based on 173 morphological and molecular attributes of the studied taxa of Acanthacea senso lato.

Inside Series II, Blepharis edulis segregated as a distinct identity at a taxonomic distance less than 1.176 owing to the incomplete looped marginal ultimate vein. The core of the present series distributed into two subseries (A \& B) at a taxonomic distance 1.176. In taxonomic context Blepharis and Acanthus are joined in the same tribe Acantheae of most current taxonomic systems [2] [5] [10] [13] [14] [50] [51] the present study did not support this combination, while the segregation of Blepharis from Series II at taxonomic distance near Acanthus group may maintain the combination of Blepharis with Acanthus in a single tribe as the previous taxonomic systems.

Subseries A that marked with valuable taxonomic traits viz. the climbing habit and the numerous sepals, included Thunbergia alata, T. grandiflora \& T. erecta, this is in agreement with [10] [13] [14] who recorded Thunbergia in a tribe Thunbergiae while [2] [50] [51] recorded the same genus in a subfamily Thunbergioideae. [52] reported that the Thunbergioideae comprised five genera, Thunbergia is the largest of them, and the subfamily is characterized by a predominantly twining habit, enlarged bracteoles, and a reduced calyx. Furthermore Thunbergioideae lack the retinaculate fruits found in core Acanthaceae.

Subseries B included two Clusters (1 \& 2) at a taxonomic distance 1.148. Cluster 1 comprised two groups; the first (Fittonia argyroneura, F.verschaffeltii \& Hypoestes sanguinolenta, [50] put Fittonia with Hypoestes in the same group. The second group contained Ruellia alba, R. brittoniana, R. humilis \& R. glabra. In a taxonomic context, [10] [13] put Ruellia in tribe Ruellieae, Cluster 2 divided into two groups at a taxonomic distance 1.12, Group I (Barleria cristata, B. prionites \& Eranthemum nervosum), the two genera have never put in a single tribe in most taxonomic systems; [10] placed Barleria and Eranthemum in two distinct tribes; Barlerieae and Eranthemeae respectively while [2] placed Eranthemum with Ruellia in tribe Ruellieae. While [14] placed the two genera in two distinct subtribes within a single tribe Justicieae and [5] \& [50] placed Barleria and Eranthemum within his tribe Ruellieae. 
Group II includes Pseuderanthemum atropurpureum, P. bicolor \& Sanchizia nobilis, Aphelandra squarossa, Odontonema cuspidatum, Anisacanthus virgularis, Justicia gendraussa, jacobinia carnea, J. specigera, Pachystachys lutea, J. adhatoda, J. betonica \& J. brandegeeana.

Pseuderanthemum atropurpureum, P. bicolor \& Sanchizia nobilis separated in a Subgroup A at a taxonomic distance less than 1.008, owing to the presence of sterile stamens. This is in accord with [50], while in contrast with [4] [5] that placed Pseuderanthemum and Sanchizia in two different tribes; Trichanthereae and Justicieae respectively.

Genus Odontonema and Aphelandra separated away from the remaining members in a subgroup B in clan 1 at a taxonomic distance less than 0.868 owing to the reticulate adaxial surface sculpture. Justicia species with Jacobinia and Pachystachys srparated in a Clan 2 at a taxonomic distance 1.036. The inclusion of Pachystachys with Justicia and Jacobinia have been recorded in tribe Gendarusseae according to [10], and in a tribe Justicieae according to [4] [5], while [2] segregated Pachystachys in a single tribe named Graptophylleae. [50] combined Eranthemum, Ruellia \& Sanchizia (subtribe Ruelliinae), Anisacanthus, Fittonia, Hypoestes, Justicia, Odontonema \& Pseuderanthemum (Subtribe Justiciinae) and Barleria (Subtribe Barleriinae) all in a single tribe Ruellieae.

\section{Conclusion}

Finally it is recommended that all of these hypotheses clearly merit additional study and need to be tested against more data, including both more characters and more taxa. For precise delimitation and the membership of them. In conclusion, the phenetic analysis of both morphological and molecular attributes clarified the segregation of genus Avicennia as a distinct identity away from Acanthaceae. Acanthus mollis \& A. montanus are isolated in its own series that comparable to tribe Acantheae of the current taxonomic systems as the same as the studied species of Thunbergia in its own subseries that comparable to tribe Thunbergiae and Ruellia in its own group that comparable to tribe Ruellieae.

\section{References}

[1] De Jussieu, A.L. (1789) Genara Plantarum. Secundum, Ordines Naturales, Disposita. Parisiis, 307.

[2] Lindau, G. (1895) Acanthacaeae. In: Engler, A. and Prantel, K., Die Naturalichen Pflanzenfamilien, Vol. 4, $274-354$.

[3] Scotland, R.W., Sweere, J.A., Reeves, P.A. and Olmstead, R.G. (1995) Higher-Level Systematics of Acanthaceae Determined by Chloroplast DNA Sequences. American Journal of Botany, 82, 266-275. http://dx.doi.org/10.2307/2445533

[4] Bremekamp, C.E.B. (1955) Notes on Some Acanthaceous Genera of Controversial Position. Acta Botanica Neerlandica, 4, 644-655. http://dx.doi.org/10.1111/j.1438-8677.1955.tb00358.x

[5] Bremekamp, C.E.B. (1965) Delimitation and Subdivision of the Acanthaceae. Bulletin of the Botanical Survey of India, 7, 21-30.

[6] Schwarzbach, A.E. and McDade, L.A. (2002) Phylogenetic Relationships of the Mangrove Family Avicenniaceae Based on Chloroplast and Nuclear Ribosomal DNA Sequences. Systematic Botany, 27, 84-98.

[7] Wortley, A.H., Harris, D.J. and Scotland, R.W. (2007) On the Taxonomy and Phylogenetic Position of Thomandersia. Systematic Botany, 32, 415-444. http://dx.doi.org/10.1600/036364407781179716

[8] Judd, W.S., Campbell, C.S., Kellogg, E.A., Stevens, P.F. and Donoghue, M.J. (2008) Lamiids (Euasterids I). In: Plant Systematics: A Phylogenetic Approach. 3rd Edition, Sinauer Associates, Sunderland, 459-494.

[9] McDade, L.A., Daniel, T.F. and Kiel, C.A. (2008) Toward a Comprehensive Understanding of Phylogenetic Relationships among Acanthaceae s.l. (Lamiales). American Journal of Botany, 95, 1136-1152. http://dx.doi.org/10.3732/ajb.0800096

[10] Nees Von Esenbeck, C.G. (1847) Acanthaceae. In: Candolle, A., Ed., Prodomus Systema Naturalis, Vol. 11, Masson, Paris, 46-519.

[11] Anderson, T. (1864) An Enumeration of the Species of Acanthaceae from the Continent of Africa and Adjacent Islands. Journal of the Linnean Society. Botany, 7, 13-54.

[12] Anderson, T. (1867) An Enumeration of the Indian Species of Acanthaceae. Journal of the Linnean Society. Botany, 9, 425-526.

[13] Clarke, C.B. (1885) Acanthaceae. In: Hooker, J.D., Ed., Flora of British India, Vol. 4, L. Reeve, London, 387-558.

[14] Bentham, G. and Hooker, J.D. (1876) Genera Plantarum. Vol. 1, Reeve, London, 57-102. 
[15] Van Tieghem, M.P. (1908) Structure du pistil et de l'ovule du fruit et de la graine des Acanthacées. Annales des Science Naturelles, Serie 9, Botanique, 7, 1-24.

[16] Wettstein, R.V. (1935) Handbuch der Systematischen Botanik, Vierte Aufl. Franz Deuticke. Leipzig and Wien.

[17] Leonard, E.C. (1951) The Acanthaceae of Colombia I. Contributions from the United States National Herbarium, 31, $1-115$.

[18] Melchior, H. (1964) Engler’s syllabus der Pflanzenfamilien. Gerbruder Borntraeger Berlin.

[19] Wasshaussen, D.C. (1966) Acanthaceae in Lundel, C.L. of Texas. Vol. 1, Renner, Texas, 276-282.

[20] Heine, H. (1962) Notes on Some West African Acanthaceae: The Reduction of the Genus Asteracantha Nees to Hygrophila R.Br. Kew Bulletin, 16, 171-173.

[21] Heine, H. (1966) Acanthaceae in Flora due Gabon, Paris.

[22] Hutchinson, J. (1973) The Families of Flowering Plants. 3rd Edition, The Clarendon Press, Oxford, 519-524.

[23] Gibson, D.N. (1974) Acanthaceae in Flora of Guatemela. Fieldiana. Botany, 24, 328-461.

[24] Thorne, R.F. (1992) Classification and Geography of the Flowering Plants. Botanical Review, 58, 225-348. http://dx.doi.org/10.1007/BF02858611

[25] Barker, R. (1986) Revision of Australian Acanthaceae. Journal of the Adelaide Botanic Gardens, 9, 1-292.

[26] Valsaladevi, G. (1987) Cytological and Palynological Studies on the South Indian Acanthaceae. Ph.D. Thesis, University of Kerala, Trivandrum.

[27] Balkwill, K. and Norris, F. (1988) Classification of the Acanthaceae. A Southern African Perspective. Monographs of Systematic Botany of the Missouri Botanical Garden, 25, 503-516.

[28] Scotland, R.W. (1993) Pollen Morphology of Contortae (Acanthaceae). Botanical Journal of the Linnean Society, 111, 471-504. http://ora.ox.ac.uk/objects/uuid:cd07aee0-b24c-4ef3-a5b8-816c0ae9e06c http://dx.doi.org/10.1111/j.1095-8339.1993.tb01916.x

[29] Gopal, S.C. and Jayantilal, A.I. (1984) Leaf Architecture of Some Acanthaceae. Botanical Magazine Tokyo, 97, 469481. http://dx.doi.org/10.1007/BF02489579

[30] Shendage, S.M. and Yadav, S.R. (2009) Cuticular Studies in Genus Barleria L. (Acanthaceae) from India. Journal of the Indian Botanical Society, 88, 176-183.

[31] Patil, A.M. and Patil, D.A. (2011) Investigations on Foliar Epidermal Characteristics in Some Acanthaceae. Current Botany, 2, 1-8.

[32] Hedren, M., Chase, M.W. and Olmstead, R.G. (1995) Relationshipsin the Acanthaceae and Related Families as Suggested by Cladistics Analysis of rbcL Nucleotide Sequences. Plant Systematics and Evolution, 194, 93-109. http://dx.doi.org/10.1007/BF00983219

[33] McDade, L.A. and Moody, M.L. (1999) Phylogenetic Relationships among Acanthaceae: Evidence from Non-Coding trnL-trnF Chloroplast DNA Sequences. American Journal of Botany, 86, 70-80. http://dx.doi.org/10.2307/2656956

[34] McDade, T.F., Daniel, S.E. and Riley, K.M. (2000) Phylogenetic Relationships within the Tribe Justicieae (Acanthaceae): Evidence from Molecular Sequences, Morphology, and Cytology. Annals of the Missouri Botanical Garden, 87, 435-458. http://dx.doi.org/10.2307/2666140

[35] Schönenberger, J. and Endress, P.K. (1998) Structure and Development of the Flowers in Mendoncia, Pseudocalyx, and Thunbergia (Acanthaceae) and Their Systematic Implications. International Journal of Plant Sciences, 159, 446465. http://dx.doi.org/10.1086/297563

[36] Täckholm, V. (1974) Student’s Flora of Egypt (ed. 2), Cairo University, 501-503.

[37] Boulos, L. (2002) Flora of Egypt. Vol. 3 (Verbenaceae-Compositae). Al Hadara Publishing, Cairo, 97-104.

[38] Bailey, L.H. (1949) Manual of Cultivated Plants. The Macmillan Company, New York.

[39] Bailey, L.H. and Bailey, E.Z. (1976) A Concise Dictionary of Plants Cultivated in the U.S. and Canada. Hortus Third "Revised by Staff of the L. H. Bailey Hortium”. The Macmillan Publishing Company. New York.

[40] Stace, C.A. (1965) Cuticular Studies as an Aid to Plant Taxonomy. Bulletin of the British Museum (Natural History) Botany, 4, 3-78.

[41] LAWG (1999) Manual of Leaf Architecture: Morphological Description and Categorization of Dicotyledonous and Net-Veined Monocotyledonous Angiosperms. Smithsonian Institution, Washington DC.

[42] Metcalfe, C.R. and Chalk, L. (1950) Anatomy of Dicotyledons. Vol. 2, Clarendon Press, Oxford.

[43] Murley, M.R. (1951) Seeds of the Cruciferae of Northeastern North America. American Midland Naturalist, 46, 1-81. http://dx.doi.org/10.2307/2421948 
[44] Prabhakar, M. (2004) Structure, Delimitation, Nomenclature and Classification of Stomata. Acta Botanica Sinica, 46, 242-252.

[45] Whitty, P.W., Powell, W. and Sprent, J.I. (1994) Molecular Separation of Genera in Cassiinae (Leguminosae), and Analysis of Variation in the Noulating Species of Chamaecrista. Molecular Ecology, 3, 507-515. http://dx.doi.org/10.1111/j.1365-294X.1994.tb00129.x

[46] Sneath, P.H. and Sokal, R.R. (1973) Numerical Taxonomy. Freeman, San Fransisco, 573.

[47] Rohlf, P.J. (2000) NTSYS-PC. Numerical Taxonomy and Multivariate Analysis Systems Exeter Publishing, New York.

[48] Abdel-Hameed, U.K., Salim, M.A., Mourad, M.M., Ishak, F.I. and Tantawy, M.E. (2014) Phylogenetic Analysis of Acanthaceae in Egypt Based on Morphological Criteria. Vegetos, 27, 29-39.

[49] A.P.G. (2009) An Update of the Angiosperm Phylogeny Group Classification for the Orders and Families of Flowering Plants: APG III. Botanical Journal of the Linnean Society, 161, 105-121. http://dx.doi.org/10.1111/j.1095-8339.2009.00996.x

[50] Scotland, R.W. and Vollesen, K. (2000) Classification of Acanthaceae. Kew Bulletin, 55, 513-589. http://dx.doi.org/10.2307/4118776

[51] Engler, A. and Prantl, K. (1897) Die Natürlichen Pflanzenfamilien nebst ihren Gattungen und wichtigeren Arten, insbesondere den Nutzpflanzen, unter Mitwirkung zahlreicher hervorragender Fachgelehrten. Leipzig: W. Engelmann, 4, 274-354.

[52] Borg, A.J., McDade, L.A. and Schönenberger, J. (2008) Molecular Phylogenetics and Morphological Evolution of Thunbergioideae (Acanthaceae). Taxon, 57, 811-822. 


\section{Appendix}

Table A1. Macromorphological characters of the studied taxa.

\begin{tabular}{|c|c|c|c|c|c|c|c|c|c|c|}
\hline $\mathrm{T}$ & Duration & $\begin{array}{c}\text { Gross } \\
\text { morphology }\end{array}$ & Habit & $\begin{array}{c}\text { Leaf } \\
\text { composition }\end{array}$ & $\begin{array}{c}\text { Leaf } \\
\text { arrangement }\end{array}$ & $\begin{array}{l}\text { Lamina } \\
\text { shape }\end{array}$ & $\begin{array}{l}\text { Lamina } \\
\text { margin }\end{array}$ & $\begin{array}{c}\text { Lamina } \\
\text { apex }\end{array}$ & $\begin{array}{l}\text { Lamina } \\
\text { texture }\end{array}$ & $\begin{array}{c}\text { Lamina } \\
\text { base }\end{array}$ \\
\hline 1 & Annual & Herb & Erect & Lobed & Decussate & Lanceolate & Sinuate & Acute & Glabrous & Cuneate \\
\hline 2 & Perennial & $\approx$ & $\approx$ & $\approx$ & $\approx$ & $\approx$ & Spiny & Acuminate & Spiny & $\approx$ \\
\hline 3 & $\approx$ & Sub-shrub & $\approx$ & Simple & $\approx$ & $\approx$ & Entire & $\approx$ & Glabrous & $\approx$ \\
\hline 4 & Annual & Herb & $\approx$ & $\approx$ & $\approx$ & Obovate & $\approx$ & $\approx$ & $\approx$ & $\approx$ \\
\hline 5 & Perennial & Sub-shrub & $\approx$ & $\approx$ & $\approx$ & Ovate & $\approx$ & $\approx$ & Hairy & $\approx$ \\
\hline 6 & $\approx$ & $\approx$ & $\approx$ & $\approx$ & $\approx$ & $\approx$ & $\approx$ & acute & $\approx$ & $\approx$ \\
\hline 7 & $\approx$ & Herb & $\approx$ & $\approx$ & Superposed & Lanceolate & Spiny & $\approx$ & $\approx$ & $\approx$ \\
\hline 8 & $\approx$ & Sub-shrub & $\approx$ & $\approx$ & Decussate & Ovate & Entire & Acuminate & Glabrous & $\approx$ \\
\hline 9 & Annual & Herb & $\approx$ & $\approx$ & $\approx$ & $\approx$ & $\approx$ & Acute & Hairy & Rounded \\
\hline 10 & $\approx$ & $\approx$ & $\approx$ & $\approx$ & $\approx$ & $\approx$ & $\approx$ & $\approx$ & $\approx$ & $\approx$ \\
\hline 11 & $\approx$ & $\approx$ & $\approx$ & $\approx$ & $\approx$ & $\approx$ & $\approx$ & $\approx$ & Glabrous & $\approx$ \\
\hline 12 & Perennial & Sub-shrub & $\approx$ & $\approx$ & $\approx$ & Lanceolate & $\approx$ & $\approx$ & $\approx$ & Cuneate \\
\hline 13 & $\approx$ & $\approx$ & $\approx$ & $\approx$ & $\approx$ & Ovate & $\approx$ & Acuminate & $\approx$ & $\approx$ \\
\hline 14 & $\approx$ & $\approx$ & $\approx$ & $\approx$ & $\approx$ & $\approx$ & $\approx$ & Acute & $\approx$ & $\approx$ \\
\hline 15 & $\approx$ & Herb & $\approx$ & $\approx$ & $\approx$ & $\approx$ & $\approx$ & $\approx$ & Hairy & $\approx$ \\
\hline 16 & $\approx$ & Sub-shrub & $\approx$ & $\approx$ & $\approx$ & Lanceolate & $\approx$ & $\approx$ & Glabrous & $\approx$ \\
\hline 17 & $\approx$ & $\approx$ & $\approx$ & $\approx$ & $\approx$ & Oblongovate & $\approx$ & $\approx$ & $\approx$ & $\approx$ \\
\hline 18 & $\approx$ & $\approx$ & $\approx$ & $\approx$ & $\approx$ & Ovate & $\approx$ & Acuminate & $\approx$ & $\approx$ \\
\hline 19 & $\approx$ & $\approx$ & $\approx$ & $\approx$ & $\approx$ & Lanceolate & $\approx$ & $\approx$ & $\approx$ & $\approx$ \\
\hline 20 & $\approx$ & $\approx$ & $\approx$ & $\approx$ & $\approx$ & Ovate & $\approx$ & Obtuse & $\approx$ & Rounded \\
\hline 21 & $\approx$ & $\approx$ & $\approx$ & $\approx$ & $\approx$ & Ovate & $\approx$ & Acute & $\approx$ & Cuneate \\
\hline 22 & Annual & Herb & $\approx$ & $\approx$ & $\approx$ & Ovate & $\approx$ & $\approx$ & Hairy & $\approx$ \\
\hline 23 & $\approx$ & $\approx$ & $\approx$ & $\approx$ & $\approx$ & Lanceolate & $\approx$ & $\approx$ & Glabrous & $\approx$ \\
\hline 24 & $\approx$ & $\approx$ & $\approx$ & $\approx$ & $\approx$ & Ovate & $\approx$ & $\approx$ & Glabrous & $\approx$ \\
\hline 25 & $\approx$ & $\approx$ & $\approx$ & $\approx$ & $\approx$ & Ovate & $\approx$ & $\approx$ & Hairy & $\approx$ \\
\hline 26 & Perennial & Sub-shrub & $\approx$ & $\approx$ & $\approx$ & Ovate & Crenate & Acuminate & Glabrous & $\approx$ \\
\hline 27 & $\approx$ & $\approx$ & Twining & $\approx$ & Superposed & Cordate & Sinuate & Acute & Hairy & Cordate \\
\hline 28 & $\approx$ & $\approx$ & $\approx$ & $\approx$ & $\approx$ & Ovate & Entire & Acuminate & Glabrous & $\approx$ \\
\hline 29 & $\approx$ & $\approx$ & $\approx$ & $\approx$ & $\approx$ & Ovate & Sinuate & $\approx$ & Glabrous & Truncate \\
\hline 30 & $\approx$ & Shrub & Erect & $\approx$ & $\approx$ & Oblongovate & Entire & Acute & Glabrous & Cuneate \\
\hline
\end{tabular}




\begin{tabular}{|c|c|c|c|c|c|c|c|c|c|c|c|c|c|c|}
\hline$T^{C}$ & Bract & $\begin{array}{c}\text { Sepal } \\
\text { No. }\end{array}$ & $\begin{array}{l}\text { Sepal } \\
\text { union }\end{array}$ & $\begin{array}{c}\text { Corolla } \\
\text { shape }\end{array}$ & $\begin{array}{c}\text { Corolla } \\
\text { tex. }\end{array}$ & $\begin{array}{c}\text { Corolla } \\
\text { tube }\end{array}$ & $\begin{array}{c}\text { No. of } \\
\text { stamens }\end{array}$ & Staminodes & L.R.C. & $\begin{array}{l}\text { Stamens } \\
\text { symmetry }\end{array}$ & $\begin{array}{c}\text { Stamens } \\
\text { tex. }\end{array}$ & $\begin{array}{c}\text { Gynoecium } \\
\text { tex. }\end{array}$ & $\begin{array}{l}\text { Stigma } \\
\text { shape }\end{array}$ & Disc \\
\hline 1 & + & 5 & United & 1-lipped & G. & Short & 4 & Absent & Exerted & Equal & G. & G. & Forked & - \\
\hline 2 & $\approx$ & $\approx$ & $\approx$ & $\approx$ & $\approx$ & $\approx$ & $\approx$ & $\approx$ & $\approx$ & $\approx$ & $\approx$ & $\approx$ & $\approx$ & $\approx$ \\
\hline 3 & $\approx$ & $\approx$ & $\approx$ & Funnel & $\approx$ & Long & 2 & $\approx$ & $\approx$ & $\approx$ & $\approx$ & $\approx$ & Single & + \\
\hline 4 & $\approx$ & $\approx$ & Free & Bilabiate & $\approx$ & $\approx$ & 4 & $\approx$ & Included & $\approx$ & $\approx$ & $\approx$ & Forked & - \\
\hline 5 & $\approx$ & 4 & United & Funnel & $\approx$ & $\approx$ & $\approx$ & $\approx$ & $\approx$ & Unequal & $\approx$ & $\approx$ & Single & + \\
\hline 6 & $\approx$ & $\approx$ & $\approx$ & $\approx$ & $\approx$ & $\approx$ & $\approx$ & $\approx$ & $\approx$ & $\approx$ & $\approx$ & $\approx$ & $\approx$ & $\approx$ \\
\hline 7 & $\approx$ & $\approx$ & Free & 1-lipped & $\approx$ & Short & $\approx$ & $\approx$ & $\approx$ & Equal & $\approx$ & $\approx$ & $\approx$ & $\approx$ \\
\hline 8 & $\approx$ & 5 & United & Funnel & $\approx$ & Long & $\approx$ & $\approx$ & Exerted & $\approx$ & $\approx$ & $\approx$ & Lobed & - \\
\hline 9 & $\approx$ & $\approx$ & $\approx$ & $\approx$ & $\approx$ & Short & 2 & $\approx$ & Included & $\approx$ & $\approx$ & $\approx$ & Single & $\approx$ \\
\hline 10 & $\approx$ & $\approx$ & $\approx$ & $\approx$ & $\approx$ & $\approx$ & $\approx$ & $\approx$ & $\approx$ & $\approx$ & $\approx$ & $\approx$ & $\approx$ & $\approx$ \\
\hline 11 & $\approx$ & $\approx$ & $\approx$ & $\approx$ & $\approx$ & $\approx$ & $\approx$ & $\approx$ & $\approx$ & $\approx$ & $\approx$ & $\approx$ & $\approx$ & + \\
\hline 12 & $\approx$ & $\approx$ & $\approx$ & Bilabiate & $\approx$ & Long & $\approx$ & $\approx$ & Exerted & $\approx$ & $\approx$ & $\approx$ & $\approx$ & $\approx$ \\
\hline 13 & $\approx$ & $\approx$ & $\approx$ & $\approx$ & $\mathrm{H}$. & Short & $\approx$ & $\approx$ & $\approx$ & $\approx$ & $\approx$ & $\mathrm{H}$. & Forked & $\approx$ \\
\hline 14 & $\approx$ & $\approx$ & $\approx$ & $\approx$ & G. & $\approx$ & $\approx$ & $\approx$ & $\approx$ & $\approx$ & $\approx$ & $\approx$ & $\approx$ & $\approx$ \\
\hline 15 & $\approx$ & $\approx$ & $\approx$ & $\approx$ & H. & Long & $\approx$ & $\approx$ & $\approx$ & $\approx$ & $\approx$ & $\approx$ & $\approx$ & $\approx$ \\
\hline 16 & $\approx$ & $\approx$ & $\approx$ & $\approx$ & G. & Short & $\approx$ & $\approx$ & $\approx$ & $\approx$ & $\approx$ & $\approx$ & $\approx$ & $\approx$ \\
\hline 17 & $\approx$ & $\approx$ & $\approx$ & $\approx$ & $\approx$ & $\approx$ & $\approx$ & $\approx$ & $\approx$ & $\approx$ & $\approx$ & $\approx$ & Single & $\approx$ \\
\hline 18 & $\approx$ & $\approx$ & $\approx$ & $\approx$ & $\approx$ & $\approx$ & $\approx$ & $\approx$ & $\approx$ & $\approx$ & $\approx$ & $\approx$ & Forked & $\approx$ \\
\hline 19 & $\approx$ & $\approx$ & $\approx$ & $\approx$ & $\approx$ & $\approx$ & $\approx$ & $\approx$ & $\approx$ & $\approx$ & $\approx$ & $\approx$ & $\approx$ & $\approx$ \\
\hline 20 & $\approx$ & $\approx$ & $\approx$ & Funnel & $\approx$ & Long & $\approx$ & 2 & Included & Unequal & $\approx$ & $\approx$ & $\approx$ & - \\
\hline 21 & $\approx$ & $\approx$ & $\approx$ & $\approx$ & $\approx$ & $\approx$ & $\approx$ & $\approx$ & $\approx$ & $\approx$ & $\approx$ & $\approx$ & $\approx$ & $\approx$ \\
\hline 22 & - & $\approx$ & $\approx$ & $\approx$ & $\approx$ & $\approx$ & 4 & Absent & $\approx$ & Equal & H. & G. & Single & + \\
\hline 23 & $\approx$ & $\approx$ & $\approx$ & $\approx$ & $\approx$ & $\approx$ & $\approx$ & $\approx$ & $\approx$ & $\approx$ & $\approx$ & $\approx$ & $\approx$ & $\approx$ \\
\hline 24 & $\approx$ & $\approx$ & $\approx$ & $\approx$ & $\approx$ & $\approx$ & $\approx$ & $\approx$ & $\approx$ & $\approx$ & $\approx$ & $\approx$ & $\approx$ & $\approx$ \\
\hline 25 & $\approx$ & $\approx$ & $\approx$ & $\approx$ & $\approx$ & $\approx$ & $\approx$ & $\approx$ & $\approx$ & $\approx$ & $\approx$ & $\approx$ & $\approx$ & $\approx$ \\
\hline 26 & + & $\approx$ & $\approx$ & Bilabiate & $\approx$ & Short & 2 & 2 & Exerted & Unequal & G. & H. & $\approx$ & - \\
\hline 27 & - & $\infty$ & Free & Funnel & $\approx$ & Long & 4 & Absent & $\approx$ & $\approx$ & $\mathrm{H}$. & G. & $\approx$ & + \\
\hline 28 & $\approx$ & $\approx$ & $\approx$ & $\approx$ & $\approx$ & $\approx$ & $\approx$ & $\approx$ & $\approx$ & $\approx$ & $\approx$ & $\approx$ & $\approx$ & $\approx$ \\
\hline 29 & $\approx$ & $\approx$ & $\approx$ & $\approx$ & $\approx$ & $\approx$ & $\approx$ & $\approx$ & $\approx$ & $\approx$ & $\approx$ & $\approx$ & $\approx$ & $\approx$ \\
\hline 30 & $\approx$ & 5 & $\approx$ & $\approx$ & $\approx$ & Short & $\approx$ & $\approx$ & Includd & $\approx$ & G. & $\approx$ & $\approx$ & - \\
\hline
\end{tabular}


Table A2. Lamina epidermal characteristics of the studied taxa (LM).

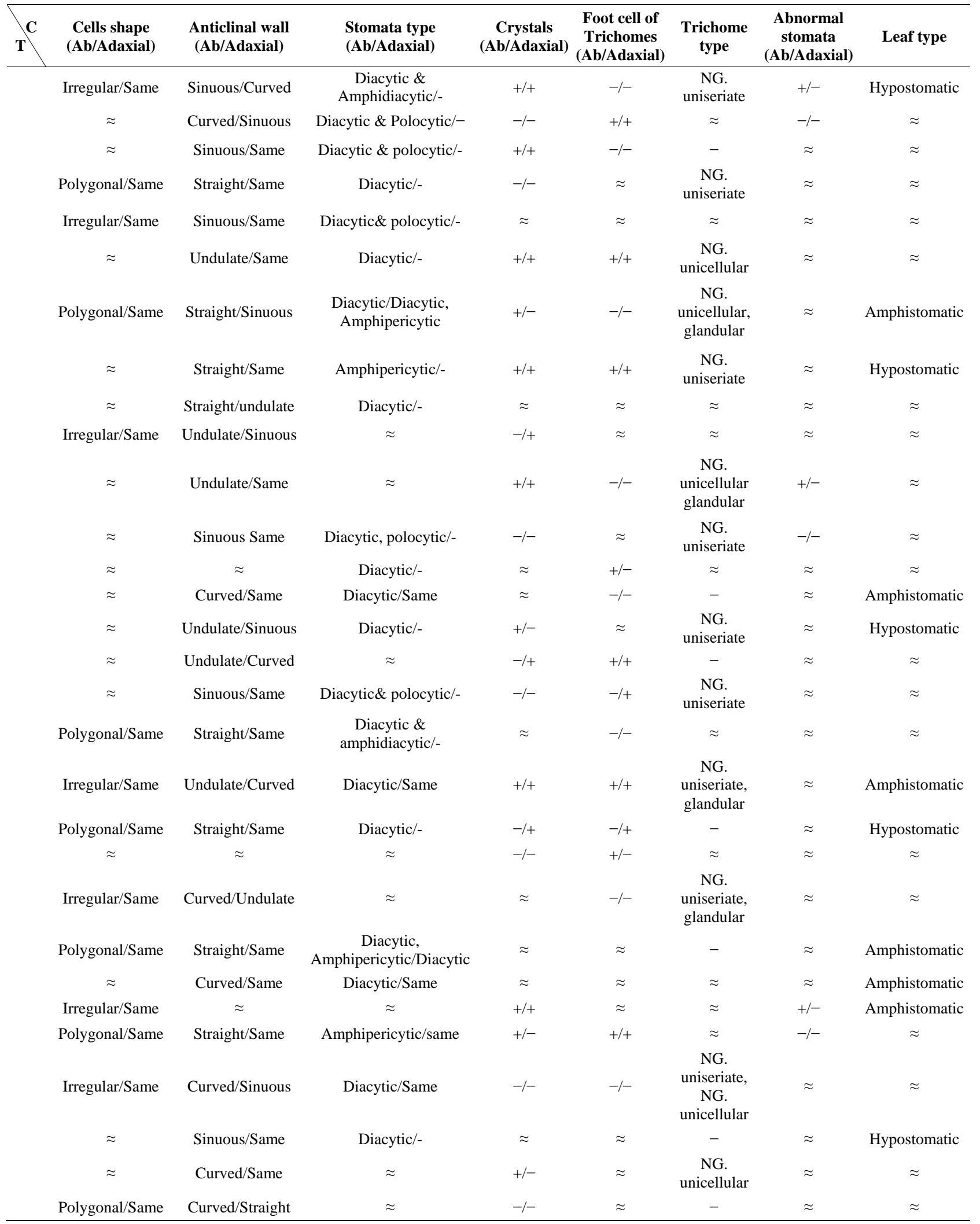

(+); Present, (-); Absent. (NG.); Non-glandular trichome. 
Table A3. Lamina epidermal characteristics of the studied taxa (abaxial surface, SEM).

\begin{tabular}{|c|c|c|c|c|c|c|}
\hline $\mathbf{T}$ & Sculpture & $\begin{array}{l}\text { Anticlinal } \\
\text { wall width }\end{array}$ & $\begin{array}{c}\text { Anticlinal wall } \\
\text { elevation }\end{array}$ & $\begin{array}{c}\text { Anticlinal } \\
\text { wall surface }\end{array}$ & $\begin{array}{c}\text { Periclinal } \\
\text { wall elevation }\end{array}$ & $\begin{array}{c}\text { Periclinal } \\
\text { wall surface }\end{array}$ \\
\hline & Ruminate & Broad & Depressed & Smooth & Raised & Smooth \\
\hline & Colliculate & Narrow & $\approx$ & $\approx$ & $\approx$ & $\approx$ \\
\hline & Ruminate & $\approx$ & $\approx$ & $\approx$ & $\approx$ & $\approx$ \\
\hline & Reticulate & $\approx$ & Raised & $\approx$ & Depressed & $\approx$ \\
\hline & $\approx$ & $\approx$ & $\approx$ & $\approx$ & $\approx$ & Striate \\
\hline & Colliculate & $\approx$ & Depressed & $\approx$ & Raised & Smooth \\
\hline & Ruminate & $\approx$ & $\approx$ & $\approx$ & $\approx$ & Striate \\
\hline & Rugose & $\approx$ & $\approx$ & $\approx$ & $\approx$ & $\approx$ \\
\hline & $\approx$ & $\approx$ & $\approx$ & $\approx$ & $\approx$ & $\approx$ \\
\hline & Reticulate & $\approx$ & $\approx$ & $\approx$ & $\approx$ & $\approx$ \\
\hline & Rugose & $\approx$ & $\approx$ & $\approx$ & $\approx$ & Smooth \\
\hline & Ruminate & Broad & Depressed & $\approx$ & Raised & $\approx$ \\
\hline & $\approx$ & $\approx$ & $\approx$ & $\approx$ & $\approx$ & $\approx$ \\
\hline & $\approx$ & $\approx$ & $\approx$ & $\approx$ & $\approx$ & Striate \\
\hline & Rugose & Narrow & Raised & $\approx$ & Depressed & $\approx$ \\
\hline & Reticulate & $\approx$ & $\approx$ & $\approx$ & $\approx$ & $\approx$ \\
\hline & Rugose & $\approx$ & $\approx$ & $\approx$ & $\approx$ & $\approx$ \\
\hline & Ruminate & $\approx$ & Depressed & $\approx$ & Raised & $\approx$ \\
\hline & $\approx$ & $\approx$ & $\approx$ & $\approx$ & $\approx$ & $\approx$ \\
\hline & Rugose & $\approx$ & Raised & $\approx$ & Depressed & $\approx$ \\
\hline & Reticulate & $\approx$ & $\approx$ & $\approx$ & $\approx$ & $\approx$ \\
\hline & Rugose & $\approx$ & $\approx$ & $\approx$ & $\approx$ & $\approx$ \\
\hline & Ruminate & $\approx$ & Depressed & $\approx$ & Raised & $\approx$ \\
\hline & $\approx$ & $\approx$ & $\approx$ & $\approx$ & $\approx$ & $\approx$ \\
\hline & $\approx$ & $\approx$ & $\approx$ & $\approx$ & $\approx$ & $\approx$ \\
\hline & $\approx$ & $\approx$ & $\approx$ & $\approx$ & $\approx$ & $\approx$ \\
\hline & $\approx$ & $\approx$ & $\approx$ & $\approx$ & $\approx$ & $\approx$ \\
\hline & Ocellate & $\approx$ & Raised & $\approx$ & Depressed & $\approx$ \\
\hline
\end{tabular}


Table A4. Lamina vein architecture of the studied taxa.

\begin{tabular}{|c|c|c|c|c|c|c|c|c|}
\hline $\mathrm{T}$ & $\begin{array}{l}1 \text { vein } \\
\text { category }\end{array}$ & $\begin{array}{l}2 \text { vein } \\
\text { category }\end{array}$ & $\begin{array}{l}2 \text { vein } \\
\text { spacing }\end{array}$ & 2 vein angle & $\begin{array}{l}\text { Inter } \\
2 \text { veins }\end{array}$ & $\begin{array}{l}3 \text { vein } \\
\text { category }\end{array}$ & $\begin{array}{l}3 \text { vein } \\
\text { course }\end{array}$ & $\begin{array}{c}3 \text { vein } \\
\text { angle to } 1\end{array}$ \\
\hline & Pinnate & $\begin{array}{c}\text { Festooned } \\
\text { semicraspedoromus }\end{array}$ & Irregular & $\begin{array}{l}\text { Abruptdly } \\
\text { increase to base }\end{array}$ & Weak & $\begin{array}{l}\text { Alternate } \\
\text { percurrent }\end{array}$ & $\begin{array}{l}\text { Exmedially } \\
\text { ramified }\end{array}$ & Acute \\
\hline & $\approx$ & Semicraspidodromus & Uniform & $\approx$ & $\approx$ & $\begin{array}{l}\text { Regular } \\
\text { polygonal } \\
\text { reticulate }\end{array}$ & $\approx$ & Obtuse \\
\hline & $\approx$ & $\approx$ & Uniform & $\begin{array}{c}\text { Smoothly } \\
\text { increase to base }\end{array}$ & Absent & Mixed & $\approx$ & $\approx$ \\
\hline & $\approx$ & $\approx$ & $\begin{array}{l}\text { Decrease } \\
\text { toward base }\end{array}$ & Uniform & Strong & $\approx$ & $\approx$ & $\approx$ \\
\hline & $\approx$ & $\approx$ & $\approx$ & $\approx$ & Absent & $\approx$ & $\approx$ & $\approx$ \\
\hline & $\approx$ & Brochidodromus & $\begin{array}{c}\text { Decrease } \\
\text { toward base }\end{array}$ & Uniform & $\approx$ & Mixed & Straight & Obtuse \\
\hline & $\approx$ & $\approx$ & $\approx$ & $\begin{array}{l}\text { Smoothly } \\
\text { increase } \\
\text { toward base }\end{array}$ & $\approx$ & $\begin{array}{l}\text { Opposite } \\
\text { percurent }\end{array}$ & Sinuous & $\approx$ \\
\hline & $\approx$ & $\begin{array}{c}\text { Festooned } \\
\text { brochidodromus }\end{array}$ & $\approx$ & $\approx$ & $\approx$ & Mixed & $\begin{array}{l}\text { Admedially } \\
\text { ramified }\end{array}$ & $\approx$ \\
\hline & $\approx$ & $\approx$ & Irregular & $\approx$ & $\approx$ & $\begin{array}{l}\text { Alternate } \\
\text { percurrent }\end{array}$ & $\approx$ & $\approx$ \\
\hline & $\approx$ & $\approx$ & $\begin{array}{c}\text { Decrease } \\
\text { toward base }\end{array}$ & Uniform & $\approx$ & $\begin{array}{l}\text { opposite } \\
\text { percurrent }\end{array}$ & Straight & Perpendicular \\
\hline & $\approx$ & $\approx$ & $\approx$ & $\approx$ & $\approx$ & Mixed & Sinuous & Obtuse \\
\hline & $\approx$ & $\approx$ & $\approx$ & Uniform & Absent & $\begin{array}{l}\text { Random } \\
\text { reticulate }\end{array}$ & $\approx$ & Acute \\
\hline & $\approx$ & Eucamptodromous & $\approx$ & $\approx$ & Weak & $\approx$ & $\approx$ & $\approx$ \\
\hline & $\approx$ & $\begin{array}{c}\text { Festooned } \\
\text { brochidodromus }\end{array}$ & Uniform & $\approx$ & Absent & Mixed & Straight & Obtuse \\
\hline & $\approx$ & $\approx$ & $\begin{array}{c}\text { Decrease } \\
\text { toward base }\end{array}$ & $\begin{array}{l}\text { Smoothly } \\
\text { increase } \\
\text { toward base }\end{array}$ & Strong & $\begin{array}{l}\text { Random } \\
\text { reticulate }\end{array}$ & $\begin{array}{l}\text { Admedially } \\
\text { ramified }\end{array}$ & $\approx$ \\
\hline & $\approx$ & $\begin{array}{c}\text { Weak } \\
\text { brochidodromus }\end{array}$ & $\approx$ & Uniform & Weak & $\begin{array}{l}\text { opposite } \\
\text { percurrent }\end{array}$ & Straight & $\approx$ \\
\hline & $\approx$ & $\begin{array}{c}\text { Festooned } \\
\text { brochidodromus }\end{array}$ & Uniform & $\begin{array}{l}\text { Smoothly } \\
\text { increase } \\
\text { toward base }\end{array}$ & Absent & Mixed & Sinuous & $\approx$ \\
\hline & $\approx$ & $\approx$ & $\approx$ & Uniform & Weak & $\begin{array}{l}\text { Random } \\
\text { reticulate }\end{array}$ & $\begin{array}{l}\text { Admedially } \\
\text { ramified }\end{array}$ & $\approx$ \\
\hline & $\approx$ & Weak brochidodromus & $\begin{array}{c}\text { Decrease } \\
\text { toward base }\end{array}$ & $\approx$ & Absent & $\approx$ & $\approx$ & $\approx$ \\
\hline & $\approx$ & $\approx$ & $\approx$ & $\approx$ & $\approx$ & $\begin{array}{l}\text { Regular } \\
\text { polygonal } \\
\text { reticulate }\end{array}$ & $\approx$ & Perpendicular \\
\hline & $\approx$ & $\begin{array}{c}\text { Festooned } \\
\text { brochidodromus }\end{array}$ & $\approx$ & $\approx$ & $\approx$ & $\begin{array}{l}\text { Alternate } \\
\text { percurrent }\end{array}$ & $\approx$ & Obtuse \\
\hline
\end{tabular}




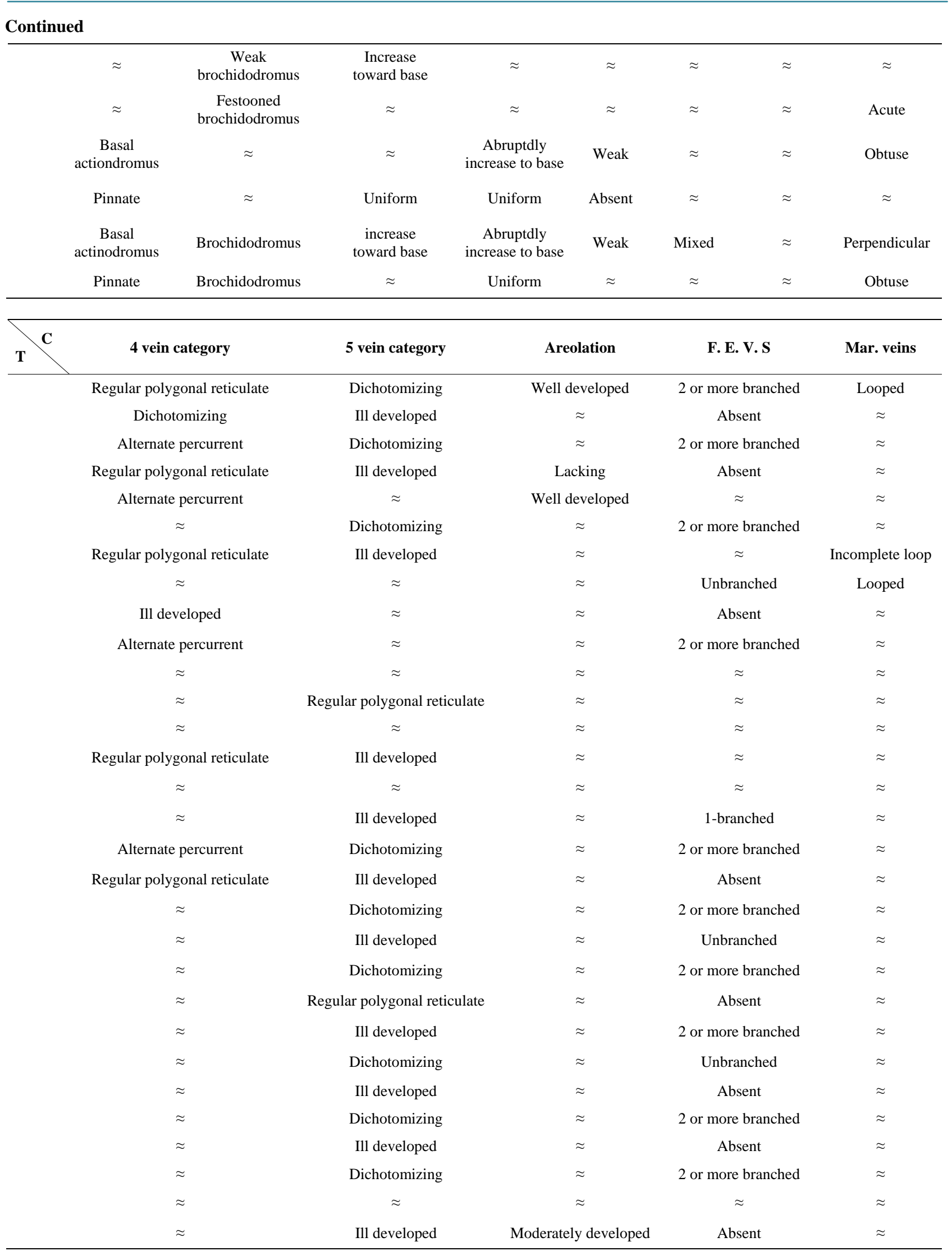

